\title{
Hydrologická bilance vybraných povodí ČR se zaměřením na suché období 2015-2019
}

RADOVAN TYL, VÁCLAV DAVID, ADAM BERAN

Klíčová slova: odtok z povodí - sucho - odtokový koeficient - časové řady - malé vodní nádrže

\section{SOUHRN}

Př́spěvek je věnován stanovení a posouzení hydrologické bilance na vybraných povodích $\vee$ České republice během suché periody $\vee$ letech 2015-2019. Hydrologická bilance byla s využitím dat ze staniční sítě Českého hydrometeorologického ústavu (ČHMÚ) zpracována k závěrovým vodoměrným stanicím v povodí Blatného potoka, Lomnice, Skalice, Žehrovky, Javorky, Cidliny, Botiče a horní Sázavy. Na povodích byly odvozeny měsiční, dlouhodobé měsíční a roční srážkové úhrny, měsiční, roční, případně dlouhodobé měsiční výšky odtoku a výšky skutečné měsiční evapotranspirace (pro měsíce duben až říjen) za období 2015-2019, které byly porovnány s odpovídajícími normálovými hodnotami za období 1981-2010. Odtoky z povodí v letech 2015-2019 byly dále porovnány s průměrem za celé období pozorování dané vodoměrné stanice.

\section{ÚVOD}

Sucho bylo v poslední době výrazně skloňovaný pojem, a to jak mezi odborníky a na poli vědy, tak i ve státní správě či mezi širokou veřejností. O suchu se pravidelně objevovaly články v médiích. Údaje o projevech sucha zpracovávají a informace o jeho průběhu nebo závažnosti přinášejí webové aplikace různých institucí (jmenujme napríklad projekt "Intersucho“ či HAMR). Problematika sucha se projednávala na vládě a byla postupně začleněna do legislativního procesu, suchem se zabývají na vědecké i akademické půdè.

V letech 2014-2019 zasáhlo Českou republiku významné sucho, které se projevilo ve všech jeho definicích, at' už to byl nedostatek srážek, vysychání půdy a nedostatek vláhy pro rostliny, pokles hladin podzemní vody ve vrtech, nebo dlouhodobý pokles průtoků ve vodních tocích.

Tato suchá epizoda byla zpracována v podobě porovnání srážek, odtoků a evapotranspirace na vybraných, relativně malých povodích v České republice, kde bylo možné využít klimatických a hydrologických dat staniční sítě ČHMú. Zpracování je součástí řešení projektu „Vliv malých vodních nádrží na hladinu podzemních vod a celkovou hydrologickou bilanci s důrazem na suchá období", kde je ČHMÚ zapojen jako spoluřešitel společně s Českým vysokým učením technickým v Praze a VúV TGM Jednou z hlavních náplní projektu je zř́zení komplexního sledování složek hydrologické bilance ve vybraných lokalitách (uvedených na obr. 1), analýza malých vodních nádrží na základě dat dálkového průzkumu Země (DPZ) či modelování hydrologické bilance povodí s malými vodními nádržemi. Projekt je zaměřen zejména na prímé sledování hydrologických veličin: hladiny ve vodním toku pro určení průtoků, hladiny v nádrži a hladiny podzemní vody v bezprostředním okolí nádrže, a navíc výparu z vodní hladiny pomocí plovoucího výparoměru. V závěrečné fázi projektu se předpokládá komplexní vyhodnocení měřených hodnot a porovnání s výsledky uvedenými v tomto článku.

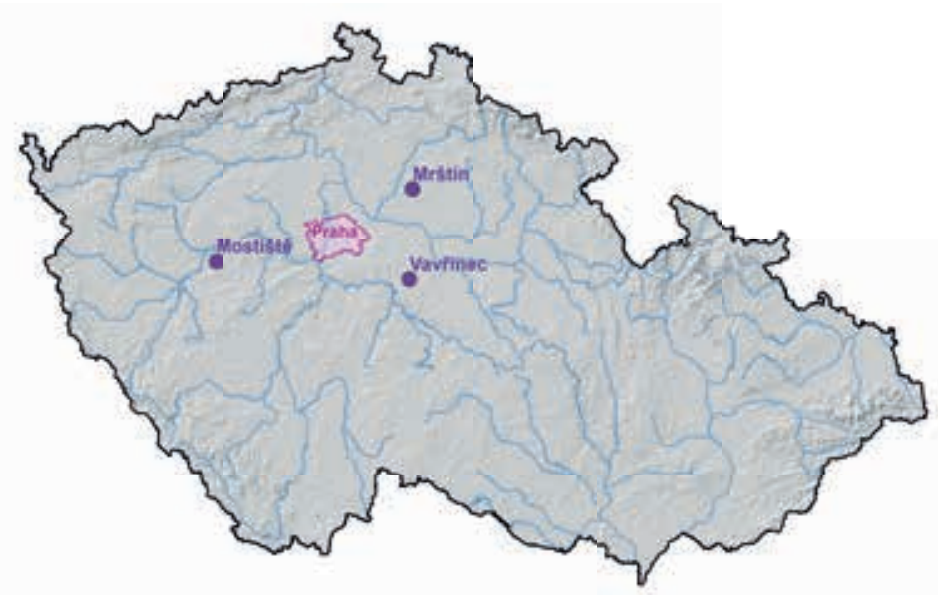

Obr. 1. Komplexní monitoring na lokalitách Vavřinec, Mrštín a Mostiště Fig. 1. Field monitoring at Vavřinec, Mrštín and Mostiště location

\section{DEFINICE HYDROLOGICKÉ BILANCE}

Základní prostorovou jednotkou pro výpočet hydrologické bilance bývá nejčastěji povodí, ale může to být i jiná plošná jednotka, např. stát nebo kontinent. Hranice povodí vymezuje fiktivní čára, rozvodnice, což je spojnice nejvyšších míst, vrcholů a hřebenů oddělující sousední povodí. Rozvodnice dělíme na orografické, kde se při stanovení bere $v$ potaz pouze orografie (povrch) terénu, nebo hydrogeologické, kde se při odvozování využívá znalostí proudění podzemní vody a geologické struktury povodí. Důležité je si uvědomit, že ne vždy korespondují orografické rozvodnice s těmi hydrogeologickými a že hodnoty složek hydrologické bilance jsou těmito skutečnostmi ovlivněny. Na velkých povodích není tento rozdíl tolik patrný, jako může být na povodích s malou plochou. Současně zejména $v$ aridních regionech s výrazně propustnými horninami mohou být rozdíly mezi výpočtem bilance nad orografickými a hydrogeologickými rozvodnicemi významné [1]. Závěrovým profilem, kde se bilancuje množství vody v povodí, bývá nejčastěji vodoměrná stanice s kontinuálním záznamem vodních stavů, respektive průtoků.

Hydrologická bilance se zpracovává vždy za nějakou časovou periodu, např. měsíc, rok, několik let či hydrologickou událost (povodeň). Zkracováním bilančního období klesá přesnost výpočtu, jelikož Ize hưře stanovit a separovat jednotlivé složky, náležející právě definovanému časovému úseku [2]. 
Výpočet hydrologické bilance vychází ze základní bilanční rovnice oběhu vody. Matematicky ji lze vyjádřit rovnicí [2, 3]:

$$
H_{S}=H_{O}+H_{V} \pm R
$$

kde

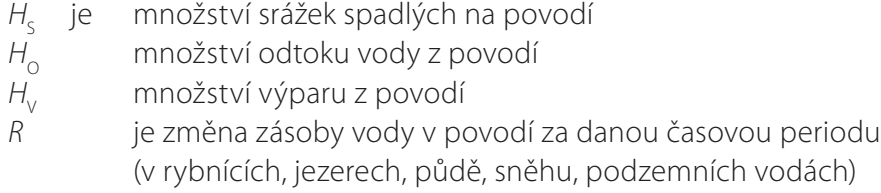

Do výparu z povodí řadíme výpar z půdy, rostlinného pokryvu, volné hladiny a transpiraci rostlin, souhrnně nazývané evapotranspirace. Hodnota evapotranspirace je prakticky vždy významnou a velmi často hlavní složkou hydrologické bilance [1], přitom je to složka obtížně kvantifikovatelná. Výjimku tvoři povodňové události s krátkou dobou trvání, při kterých je územní výpar ve srovnání s ostatními složkami hydrologické bilance zpravidla nepoměrně menši a často je z toho důvodu zanedbáván. Za předpokladu, že se množství vody $\checkmark$ povodí za vybranou časovou periodu nemění, tedy $R$ se rovná nule, Ize rovnici hydrologické bilance zjednodušit na tvar:

$$
H_{S}=H_{0}+H_{V}
$$

V České republice zpracovává ČHMú každoročně hydrologickou bilanci (viz např. [4]), v niž se pro 10 dílčích povodí uvádějí hodnoty o atmosférických srážkách, celkovém a základním odtoku, zásobách vody ve sněhové pokrývce, změnách zásob podzemní vody a přirozených průtocích ve vybraných vodních tocích. Zpracování hydrologické bilance ČR je dáno zákonem 254/2001 Sb., o vodách a o změně některých zákonů (vodní zákon), podrobnosti stanovuje vyhláška Ministerstva zemědělství 431/2001 Sb., o obsahu vodní bilance, způsobu jejího stanovení a údajích pro vodní bilanci.

\section{ZPRACOVÁNÍ DAT}

\section{Srážky}

Roční, měsíční a dlouhodobé měsíční rastry srážek byly odvozeny s využitím orografické interpolace z bodových pozorování ve srážkoměrných stanicích. Pro vybraná povodí byly hodnoty srážek následně stanoveny jako prostý plošný průměr.

\section{Odtoky}

Roční a měsiční odtoky jsou v tomto článku uváděny jako odtoková výška, což představuje výšku vody na povodí v milimetrech za dané časové období. Jedná se o objem vody, proteklý závěrovým profilem za danou časovou jednotku, rovnoměrně rozprostřený na plochu povodí. Odtoky byly spočítány z pozorovaných hodnot vodních stavů, jež jsou pomocí měrných křivek preváděny na průtoky.

\section{Odtokový koeficient}

Podílem odtoku a srážky dostaneme hodnotu odtokového koeficientu, což je hodnota, která vyjadřuje relativně nebo procentuálně, jaké množství vody ze spadlé srážky odteče závěrovým profilem, opět za danou jednotku času.

\section{Zpracování evapotranspirace}

Výpočet potenciální a skutečné evapotranspirace probíhá v ČHMÚ na pobočce Brno prostřednictvím agrometeorologického modelu AVISO (Agrometeorologická výpočetní a informační soustava). Vstupem do modelu jsou meteorologická data pro soubor 198 automatických klimatologických stanic staniční sítě ČHMú, výstupem jsou modelovaná data agrometeorologických charakteristik v bodové síti [5].

Jedním z dalších výstupů, kde se bodové hodnoty evapotranspirace používají, je Indikátor prívalových povodní (flash flood indicator, zkráceně FFI). Bodové hodnoty skutečné evapotranspirace (odhad pro středně těžké půdy, písčitohlinité až hlinité půdy a pro půdní pokryv typu travní porosty) jsou interpolovány $v$ denním kroku do rastru pomocí interpolační metody vážené inverzní vzdálenosti (IDW, inverse distance weighted interpolation) a vstupují do dalších výpočtů Indikátoru prívalových povodní.

Z denních rastrů skutečné evapotranspirace vstupujících do výpočtů FFI byly $\vee$ prostředí GIS s využitím matematické algebry spočítány měsíční sumy pro období duben až řijen v letech 2015-2019 a z nich byly odvozeny průměry měsíčních hodnot na jednotlivá povodí. Výpočet FFI, a tudíz i evapotranspirace, probíhá od roku 2011, nebylo proto možné porovnat odvozené hodnoty s dlouhodobým průměrem za léta 1981-2010.

\section{VÝBĚR A POPIS VYBRANÝCH LOKALIT}

Povodí, která byla vybrána pro výpočet hydrologické bilance, musela splňovat několik - často protichůdných - kritérií. Výběr byl prováděn zejména s ohledem na zadání projektu, tedy aby zde bylo možné zkoumat interakci malých vodních nádrží s hladinou podzemní vody v blízkém okolí, jejich vliv na hydrologickou bilanci a zaměření na suchá období. Výběr probíhal ve více úrovních s tím, že k povodím, na nichž zatím nebyla provedena žádná analýza, je možné se v průběhu řešení projektu vrátit a do souboru lokalit je doplnit.

vybraná kritéria výběru povodí (ve vztahu k celkové náplni zmíněného projektu):

- existence rybníku, malé vodní nádrže nebo soustavy malých vodních nádrží (MVN)

— velikost plochy povodí do max. $500 \mathrm{~km}^{2}$

- prípadné pozorování na prítoku do nádrže a na odtoku z nádrže, ovšem na nádrži bez manipulací a odběrů

- existence relativně dlouhé řady pozorování vodních stavů a vyhodnocení průtoků

- dostupnost dat o hladinách podzemních vod v mělkých vrtech, ideálně v rozumném okolí MVN

— k dispozici data o výparu

- odlišné geologické podmínky ve srovnání s lokalitami Mrštín, Vavřinec a Mostiště 
Přehled lokalit, které byly zpracovány v tomto príspěvku, přináší mapa na obr. 2.

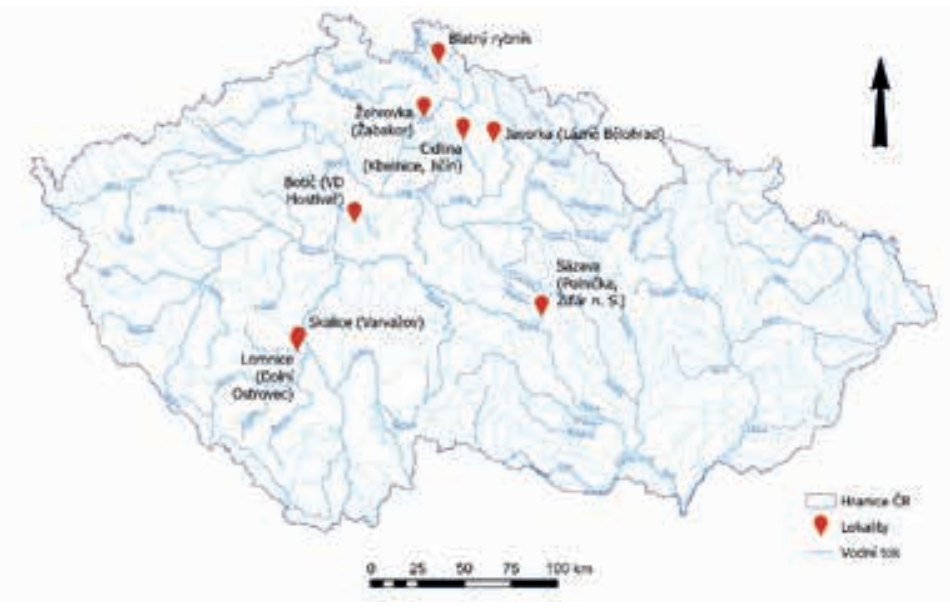

Obr. 2. Lokality s provedenou analýzou hydrologické bilance

Fig. 2. Location of interests with the hydrologic balance analysis

\section{Blatný rybník}

Tato lokalita je zcela odlišná od ostatních vybraných, zejména co se týká nadmořské výšky, respektive klimatických podmínek $v$ průběhu roku. Povodí se nachází v nejvyšších partiích Jizerských hor s rašeliništi, rašelinnými loukami a smrčinami v pramenné části. Průměrná nadmořská výška povodí je 820 m n. m. Geologickou strukturu podloží tvoří granity až granodiority doplněné slatinami, rašelinami a hnilokaly [6]. Na odtoku z rybníka existuje vodoměrné pozorování ve stanici Blatný potok s malými výpadky od roku 1988 (plocha povodí $A=4,76 \mathrm{~km}^{2}$ ). $\vee$ rámci projektu bylo rozhodnuto o pořízení a instalaci nové vodoměrné stanice na prítoku do rybníka, která proběhla na konci dubna 2020.

\section{Botič (VD Hostivař)}

V povodí Botiče bylo v průběhu let 2014 a 2015 rekonstruováno a převzato do částečné správy ČHMÚ mnoho vodoměrných stanic, mj. na př́toku do VD Hostivař (stanice Praha-Petrovice, $A=87,62 \mathrm{~km}^{2}$ ) a na odtoku z VD Hostivař (stanice Praha-Hostivař, $A=95,46$ km²). Řady vodních stavů nejsou dlouhé, ale je možné porovnat přitoky a odtoky pro aktuální suché období. Při analýze časových řad průtoků je třeba brát v úvahu, že na VD Hostivař se udržuje rozdílná letní a zimní hladina, tudíž že na podzim dochází k odpouštění nádrže, na jaře zase k dopouštění. Kromě těchto jarních a podzimních změn hladin se na nádrži nemanipuluje, slouží zejména k rekreačním účelưm. Přímo do nádrže je zaústěn nepozorovaný Hájecký potok, odvodňující části severního okraje Jižního Města, což může komplikovat vyhodnocení za povodňových situací.

\section{Žehrovka (rybník Žabakor)}

K dispozici jsou data z vodoměrných stanic Ždár u Svijan (1941-1973, stanice nad rybníkem) a Březina (1974 - současnost, stanice pod rybníkem). Povodí je zajímavé tím, že se nachází v oblasti České křídové tabule s kvarterními sprašovými hlínami, křemenci a sedimenty, tedy s výrazně odlišnými horninami, než jsou lokality Vavřinec a Mrštín. Nevýhodou je skutečnost, že rybník Žabakor není na hlavním toku, ale je boční, s obtokem, a je tudíž problematické stanovit přesné množství vody protékající rybníkem.

\section{Cidlina (Kbelnice, Jičín) a Javorka (Lázně Bělohrad)}

Jedná se o dvojici povodí s odlišným procentuálním zastoupením rybníků. V povodí Javorky je vodoměrná stanice Lázně Bělohrad $(A=38,35$ km²), v povodí Cidliny jsou k dispozici data z vodoměrné stanice Jičín $(A=39,39$ km²), respektive Kbelnice. Stanice Lázně Bělohrad měři vodní stavy od roku 1929 do současnosti (s nepatrnými výpadky v roce 2005), stanice Jičín měří od roku 1956, v letech 1975-2003 jsou data této stanice nahrazena pozorováním ve stanici Kbelnice. Velikostí plochy jsou obě povodí srovnatelná.

\section{Lomnice a Skalice}

Lomnice a Skalice jsou sousední povodí v jižních Čechách. Na obou je závěrová stanice sledující vodní stavy shodně v provozu od roku 1931, povodí jsou zhruba stejně velká (plocha ke stanici je cca $370 \mathrm{~km}^{2}$ ), na druhou stranu jsou zde plochy malých vodních nádrží zastoupeny v rozdílném měřítku. Vodní plochy v povodí Lomnice zabírají 3,66 \%, v povodí Skalice je to 1,54 \% plochy povodí. Přímo v povodí Lomnice se nachází profesionální klimatická stanice Kocelovice, kde jsou kromě srážek a teplot k dispozici také údaje o výparu nebo solární radiaci. Zároveň jsou zde dostupná data o hladinách podzemní vody v mělkých vrtech, a to zhruba od 60. let minulého století.

\section{Sázava (Polnička, Žd'ár nad Sázavou)}

V pramenné části Sázavy se nachází rybník Velké Dářko se zatopenou plochou 205 ha. Po jeho vybudování v 15. století došlo k částečné změně hydrologických poměrů v pramenné oblasti Sázavy a rozšîrení rašelinišť v plochém rozvodí Českomoravské vrchoviny [7]. Od roku 2004 jsou k dispozici data z vodoměrné stanice Ždár nad Sázavou $\left(A=132,68 \mathrm{~km}^{2}\right)$. V povodí se nacházejí další vodní nádrže - Pilská, Bránský rybník, Strž a Staviště. Data z vodoměrných stanic nejsou dostupná za př́liš dlouhé období. Stanice se nacházejí v lokalitě s velkým podílem vodních ploch, které v letním a suchém období mohou mít významný výpar z vodní hladiny.

\section{ROČNÍ ÚHRNY SRÁŽEK A ODTOK VODY Z POVODÍ}

Roční plošné úhrny srážek pro normálové období 1981-2010 (v grafech na obr.3 zelená čára) jsou porovnány s ročními plošnými úhrny v jednotlivých letech suchého období 2015-2019 (modré sloupce) a odpovídajícími ročními odtoky (žluté sloupce). Červenou čarou je znázorněn prưměr ročních srážek na povodí za období2015-2019. Uvedeny jsou vodoměrné stanice, jež mají ve zkoumaném období alespoň částečné sledování. Stanice na Botiči v Praze začaly pozorovat ažv červnu 2016, proto jsou v grafech uvedeny odtoky pouze pro roky 2017-2019. Data ročních srážek a odtoků byla zpracována v rozmezí periody kalendáŕního roku.

V rámci sledovaného období 2015-2019 byl srážkově nejbohatší rok 2017. Výrazně nad normálovou hodnotou za referenční období i nad průměrem za periodu 2015-2019 jsou plošné srážky v severní části republiky (Blatný potok, Žehrovka, Cidlina a Javorka). Na ostatních povodích se srážka za rok 2017 pohybuje okolo normálu, kromě stanice Dolní Ostrovec na Lomnici, kde vychází v roce 2016 větší srážkový úhrn než v roce 2017, a stanice Ždár nad Sázavou, kde je větší srážka v roce 2019 než 2017. Jednoznačně nelze určit ani nejsušší rok. Na většině povodí napršelo nejméně za rok 2018, ovšem v povodí Lomnice a Skalice je nejsušší rok 2015. 

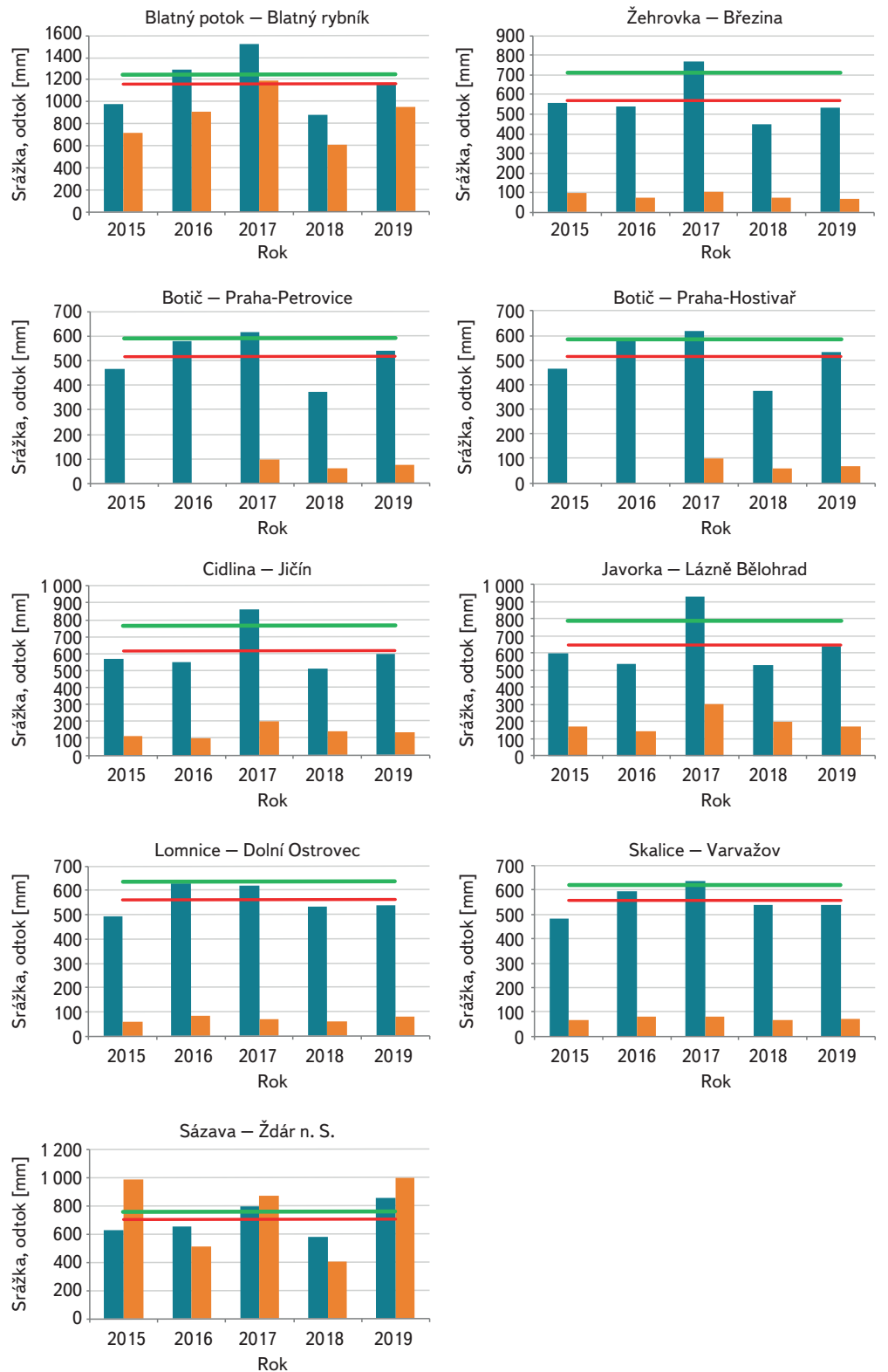

\section{Srážka} Odtok

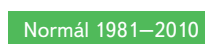

\section{Průměr 2015-2019}

Obr. 3. Průběh ročních srážek a odtoků ve vybraných povodích

Fig. 3. Annual precipitation and runoff in selected river catchments

Blatný potok má zcela odlišný režim odtoku od ostatních povodí. Odtokové koeficienty se ve zkoumaném pětiletí pohybují v rozmezí 0,7 až 0,8, tedy že ze spadlých srážek odtéká 70 až 80 \% vody závěrovým profilem povodí. To je dáno vysokou nadmořskou výškou povodí, kde se dlouho do jara drží sníh, který postupně odtává, a přispívá tak k odtoku v bezesrážkovém období.

Pokud porovnáme srážky a odtoky sousedních povodí Cidliny a Javorky, můžeme konstatovat, že srážek spadlo více v povodí Javorky a také odtoky $\checkmark$ něm byly vyšší, tedy i odtokové koeficienty zde vycházejí pro všechny roky nepatrně větší a pohybují se v intervalu 0,26 až 0,38, kdežto v povodí Cidliny dosahují odtokové koeficienty hodnot mezi 0,18 až 0,28.

Povodí Lomnice a Skalice mají hodnoty srážek a odtoků srovnatelné, opět jsou nepatrně větší odtokové koeficienty ve stanici Varvažov. Odtokové koeficienty jsou ve zkoumaném období 2015-2019 pro jednotlivé roky velmi vyrovnané (ve stanici Dolní Ostrovec jsou to hodnoty 0,11 až 0,14, u stanice Varvažov se pohybují v intervalu 0,13 až 0,14).
Zajímavé jsou odtoky na Sázavě v profilu Ždár nad Sázavou. V letech 2015, 2017 a 2019 prekračují hodnoty odtoku hodnoty spadlých srážek, což znamená, že z povodí odteklo více vody, než spadlo v podobě srážek. V roce 2015 je tato hodnota více než 1,5krát větší oproti srážce. Jedním z faktorů ovlivňujících odtoky je jistě podzimní výlov rybníka Velké Dářko (proběhl na podzim 2015 i 2017), dalším prvkem přispívajícím k většímu odtoku mưže být přitomnost rašeliništ v pramenných partích Sázavy a ovlivňovat průtoky mưže také plánovaná, respektive realizovaná rekonstrukce stavebních objektů vodních děl v povodí (Pilská, Strž, Staviště), př̌i nichž dochází k odpouštění vody z nádrže.

\section{MĚSÍČNÍ ÚHRNY SRÁŽEK A ODTOKY VODY Z POVODÍ}

Současně se zpracováním roční bilance byly na vybraných povodích zpracovány také měsíční hodnoty plošných srážek a odtoků (obr. 4-9). U srážek byly spočítány dlouhodobé měsiční normály pro referenční období 1981-2010 (v grafech světle modrá čára) a měsiční srážky pro každý rok období 2015-2019, na následujících obrázcích jsou zobrazeny na grafech umístěných vlevo. Grafy vpravo ukazují měsiční odtoky za období 2015-2019. Žlutá čára představuje průměry jednotlivých měsíčních odtoků za celé období pozorování stanice (to je u každé stanice jiné a je uvedeno $v$ popisku grafu). Pokud jsou pro závěrovou vodoměrnou stanici k dispozici pozorování pro referenční období 1981-2010 (normálové období), jsou do grafu odtoků navíc světle modrou čarou zaneseny dlouhodobé průměrné měsíční odtoky pro tuto periodu.

\section{Blatný potok - Blatný rybník}

Průběh normálových srážek v letech 1981-2010 (obr. 4) byl jen mírně rozkolísaný v průběhu roku a dosahoval maxima v letních měsících červenci a srpnu. Výrazně podnormální byly srážky v únoru 2015 (24\% normálu) a v podstatě všechny měsíce roku 2018 ( $v$ únoru 2018 to bylo jen 12 \% normálu). Nejvíce srážek spadlo v říjnu 2017 (291 \% normálu), listopadu 2015 (208 \%) a prosinci 2018 (231 \%). Odtoky byly nejvyšší v jarních měsících, zejména v dubnu, s následujícím vyrovnaným průběhem od června a zasahující až do ledna následujícího roku. Přesto byly letní a podzimní odtoky zřetelně pod svými průměry, nejvíce v letech 2015, 2018 a 2019.
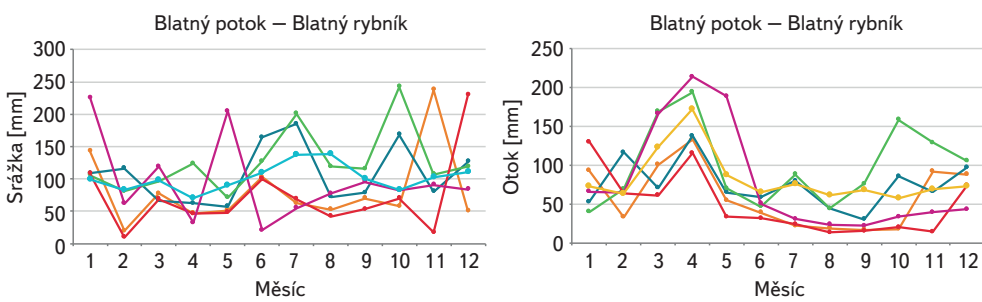

\section{\begin{tabular}{l|l|l|l|l}
2015 & 2016 & 2017 & 2018 & 2019
\end{tabular}}

Obr. 4. Měsíční srážky (vlevo) a odtoky (vpravo) v povodí Blatného potoka

Fig. 4. Monthly precipitation (left) and runoff (right) in Blatný brook catchment

\section{Botič - VD Hostivař}

Měsíční průběh normálových srážek, jak je patrné z grafů na obr. 5, má typický roční průběh s hodnotami mezi 30-40 mm na jaře, na podzim a v zimě a s maximálními úhrny v letních měsících, nejvíce v červenci (shodně 84 mm). V suchých rocích 2015 a 2018 byl nad čárou normálu jen řijen a listopad roku 2015. Data odtoků jsou k dispozici za velmi krátké období, od července 2016. I tak je jasně 
patrný vliv vodní nádrže na odtokové stanici, kdy od dubna do srpna 2018 jsou hodnoty odtoku ve stanici Hostivař menší než na př́toku ve stanici Petrovice. Na průměrných hodnotách odtoků za období 2016-2019 (žlutá čára) je dále patrný rozdílný letní a zimní provoz nádrže. Během dubna dochází k plnění nádrže na vyšši letní hladinu, naopak v řínnu dochází k odpouštění nádrže a snižování hladiny na zimní úroveň. Za pozorované období byly trochu překvapivě větší prítoky do nádrže v listopadových měsících 2016 a 2017, kdy bývají odtoky z povodí obvykle nízké, což ovšem odpovídá výrazně nadnormálním srážkovým úhrnům v řínnových měsících.
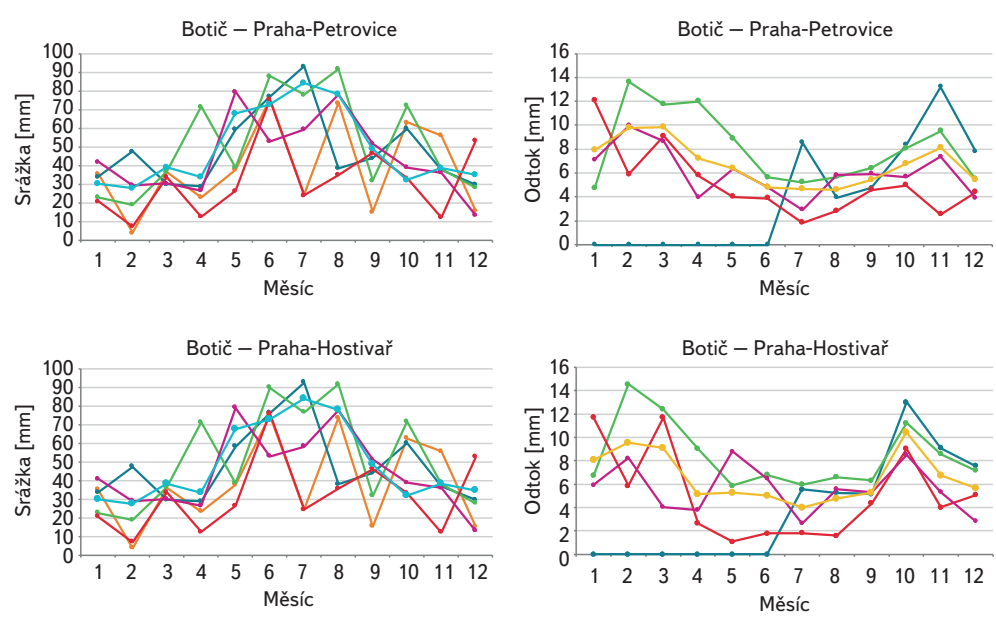

\begin{tabular}{|l|l|l|l|l|l|l|l|}
\hline 2015 & 2016 & 2017 & 2018 & 2019 & $1981-2010$ & Odtok 1986-2019 \\
\hline
\end{tabular}

Obr. 5. Měsíční srážky (vlevo) a odtoky (vpravo) pro VD Hostivař (na prítoku vodoměrná stanice Praha-Petrovice, na odtoku stanice Praha-Hostivař)

Fig. 5. Monthly precipitation (left) and runoff (right) for water reservoir Hostivař (inflow: Praha-Petrovice water level gauge station, outflow: Praha-Hostivař water level gauge station)

\section{Žehrovka}

Na obr. 6 jsou uvedeny měsíční srážky a odtoky k závěrové stanici Březina na Žehrovce. Srážkově chudé oproti normálu byly zejména únorové měsíce (kromě února 2016), nejhorší průběh, co se týče měsíčních průměrů, je patrný pro rok 2018. Odtoky byly hluboko pod průměrem let 1981-2010 i pod průměrem za celé období pozorování stanice. Zvětšené odtoky se neprojevily ani při srážkově bohatém červnu a červenci v letech 2016 a 2017. Nejhorší byla situace v létě 2018 a 2019, kdy odtoky dosahovaly 12 až 20 \% průměru za období pozorování. K větším odtokům dochází pouze v březnu a říjnu, kdy jsou v povodí pravděpodobně prováděny manipulace.
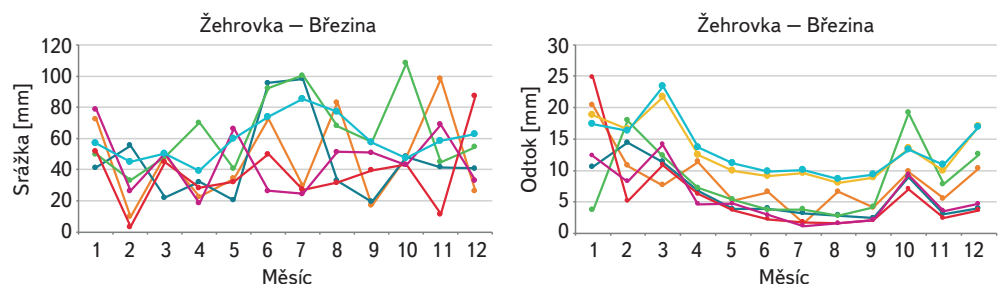

\begin{tabular}{l|l|l|l|l|}
2015 & 2016 & 2017 & 2018 & 2019
\end{tabular}

Obr. 6. Měsíční srážky (vlevo) a odtoky (vpravo) v povodí Žehrovky

Fig. 6. Monthly precipitation (left) and runoff (right) in Žehrovka catchment

\section{Cidlina a Javorka}

Srážkově výrazně podnormální jsou opět únorové měsíce, jak je patrné z obr. 7. Na povodí Cidliny činil srážkový úhrn v únoru 2018 jen 3 mm (6 \% normálu), na povodí Javorky 3,5 mm (7 \% normálu). Měsíční odtoky byly ve všech letech 2015-2019 pod čárou průměru let 1981-2010 i průměru za období pozorování (Cidlina od roku 1955, Javorka od roku 1928). Výjimkou byly podzimní odtoky v roce 2017 a následně odtok v lednu 2018.
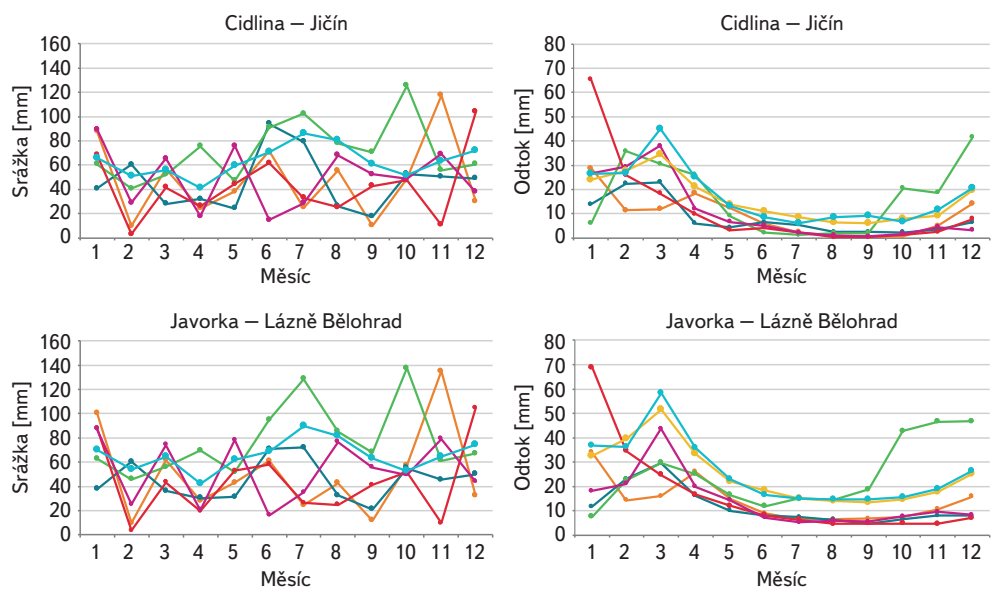

\section{5}

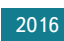

2017

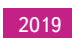

\section{$1981-2010$}

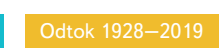

Obr. 7. Měsíční srážky (vlevo) a odtoky (vpravo) v povodí Cidliny a Javorky Fig. 7. Monthly precipitation (left) and runoff (right) in Cidlina and Javorka catchment

\section{Lomnice a Skalice}

Průběhy srážek i odtoků v povodí Lomnice a Skalice jsou si velmi podobné (obr. 8). Nad normálem výrazně vyčnívá srážkový úhrn v červenci 2016, což se projevilo i vyššími odtoky v tomto měsíci. V povodí Skalice byly srážkově významné i úhrny v červnu 2016 a květnu 2018, v povodí Lomnice již méně (ale i tak vyšší než normál). Možná i proto nebyl rok 2018 srážkově nejchudší, tím byl rok 2015. Odtoky v červenci a srpnu 2018 a 2019 byly na kritických hodnotách (1 až 5 \% obvyklého dlouhodobého průměru). Vodnější byl v letních měsících rok 2016, přičemž v červenci byl odtok nad oběma hodnotami průměru. $\checkmark$ povodí Lomnice dochází, opět pravděpodobně vlivem odpouštění rybníků, k nárůstu odtoků v říjnových měsících.
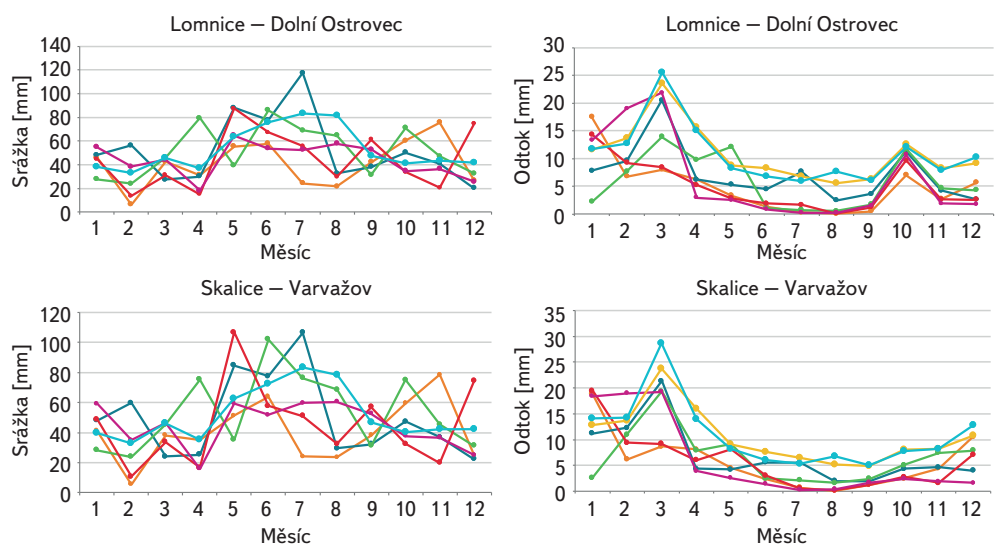

\begin{tabular}{l|l|l|l|l}
2015 & 2016 & 2017 & 2018 & 2019
\end{tabular}

Obr. 8. Měsíční srážky (vlevo) a odtoky (vpravo) v povodí Lomnice a Skalice

Fig. 8. Monthly precipitation (left) and runoff (right) in Lomnice and Skalice catchment 


\section{Sázava}

Jak uvádí zpráva podniku Povodí Vltavy [7], u Cenomanského kolektoru je odvodnění plynulým prítokem do přirozených vodních nádrží a slatiništ (rybníky Malé a Velké Dářko), které významnou měrou napájejí povrchové toky a nadlepšují jejich vodnost (zejména u řeky Sázavy). Srážkově i odtokově nejchudší byl rok 2018, přitom ale, jak je zrejmé z ročního zpracování, odtokový koeficient dosahoval $69 \%$, což potvrzuje výše uvedené konstatování o dotaci podpovrchovou vodou. Oproti průměru jsou odtoky ze suchého pětiletí zejména v letním období menší, s minimy v roce 2018.
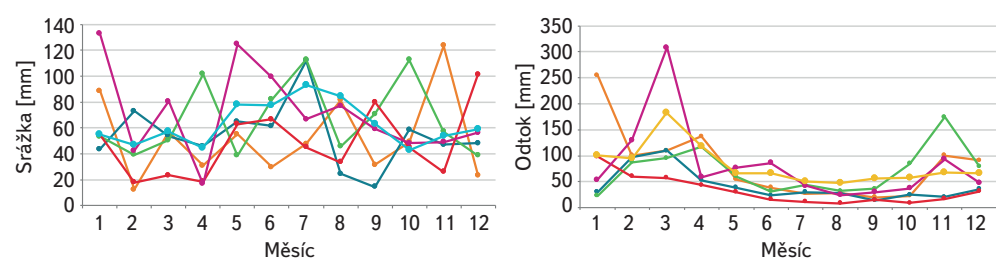

$1981-2010$

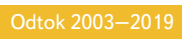

Obr. 9. Měsíční srážky (vlevo) a odtoky (vpravo) v povodí horní Sázavy Fig. 9. Monthly precipitation (left) and runoff (right) in upper Sázava catchment

\section{MĚSÍČNÍ HODNOTY EVAPOTRANSPIRACE NA VYBRANÁ POVODÍ}

Měsíční hodnoty skutečné evapotranspirace vykreslují grafy na obr. 10. Pro srovnání jsou hodnoty uvedeny ve stejném měřítku na ose y. Výpočet evapotranspirace na jednotlivá povodí proběhl za zkoumané období 2015-2019. K dispozici byla data za konvektivní sezonu, tedy od dubna do ř́ina, kdy je $\vee$ provozu Indikátor přivalových povodní. V roce 2016 byla k dispozici data i pro měsíc březen.

Nejvyšších hodnot evapotranspirace bylo dosaženo v červnu 2019, a to shodně pro všechna zkoumaná povodí. Výjimkou je pouze povodí Cidliny, kde byla největší hodnota v květnu roku 2018. Velkých hodnot ve všech povodích dosahovala evapotranspirace také v průběhu celého roku 2017 (zelená čára). Zajímavý je průběh evapotranspirace v létě roku 2018 jakožto nejsuššího roku zkoumaného období, prìtom kromě povodí Blatného rybníka, Lomnice a Skalice jsou hodnoty evapotranspirace jedny z nejnižších.

\section{SHRNUTÍ VÝSLEDKU゚}

Na vybraných povodích byly odvozeny měsiční, dlouhodobé měsiční, prípadně roční hodnoty jednotlivých částí hydrologické bilance za suché období 2015-2019, které byly porovnány s normálovou periodou 1981-2010.

Pro stanovené suché pětiletí nelze úplně jednoznačně určit jeden společný rok s minimálním ročním úhrnem srážek, tedy rok, který by byl nejsušši z pohledu meteorologického. V roce 2018 byly nejnižší srážky ve všech povodích kromě povodí Lomnice a Skalice v jižních Čechách, kde byl srážkový úhrn v roce 2015 ještě nižší. Naopak srážkově nejbohatší byl rok 2017, opět ale ne ve všech lokalitách. V povodí horní Sázavy byl srážkově nejbohatší rok 2019, v povodí Lomnice to byl rok 2016. Rok 2017 byl na většině povodí nad dlouhodobým normálem 1981-2010.

Fakt, že všechna povodí nebyla srážkově zasažena stejně, potvrzují mapy na obr. 11, kde jsou znázorněny úhrny srážek v procentech normálu 1981-2010 (publikovaných na oficiálních stránkách ČHMú). Z nich vyplývá, že rozložení srážek napříc republikou bylo $v$ jednotlivých letech výrazně nerovnoměrné, a tudiž i projevy deficitu srážek ve zkoumaných povodích byly rozdílné. Patrné
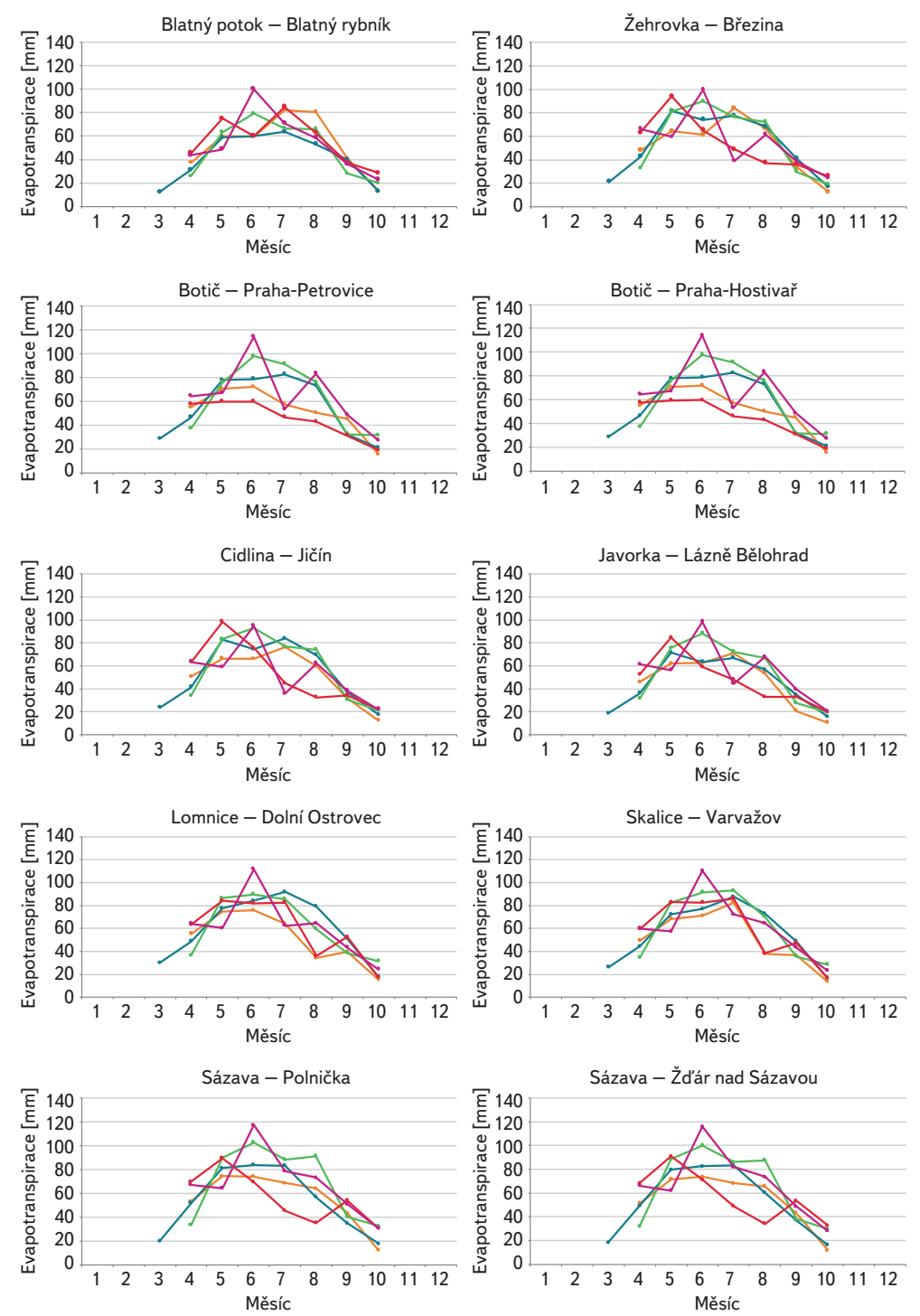

\section{\begin{tabular}{l|l|l|l|l}
2015 & 2016 & 2017 & 2018 & 2019
\end{tabular}}

Obr. 10. Průběh evapotranspirace pro jednotlivá povodí

Fig. 10. Annual evapotranspiration for individual river catchments

je to zejména v roce 2016, kdy byly srážky podnormální v pásu od Krkonoš přes Vysočinu po horní Podyjí, v roce 2017, kdy byly srážky podnormální v jižní polovině republiky (Šumava a jižní Morava), a v roce 2019, kdy bylo srážek méně v západní polovině republiky.

Povodí Blatného rybníka má oproti ostatním zkoumaným povodím odlišný odtokový režim s podílem odtoku ze spadlých srážek okolo 75 \%. Výraznou měrou se na odtoku podílí jak dotace podpovrchové vody z pramenných rašelinišť, tak vysoká nadmořská výška, kdy dochází k postupnému odtávání sněhové pokrývky během zimy a na jaře, a to i přesto, že v roce 2015 a 2018 byly zimy srážkově velmi chudé (zejména v únoru). Jak uvádí hydrologická ročenka ČHMÚ [4], na dílčí povodí Horního a středního Labe spadlo v únoru 2018 jen 9 mm srážek, což činí $21 \%$ normálu, respektive vodní hodnota sněhu byla v únoru 2018 jen 9,3 mm (32\% normálu).

Rok 2018 a především jeho letní měsíce (nejvíce srpen) jsou v rámci sledovaného období 2015-2019 jednoznačně nejsušší v prípadě odtoků na všech zpracovaných povodích. Hydrologické sucho zasáhlo významně celé území ČR, $\checkmark$ mnoha vodoměrných stanicích byly zaznamenány průtoky pod hranici $Q_{355 d^{\prime}}$ respektive $Q_{364 d}$ [8]. 

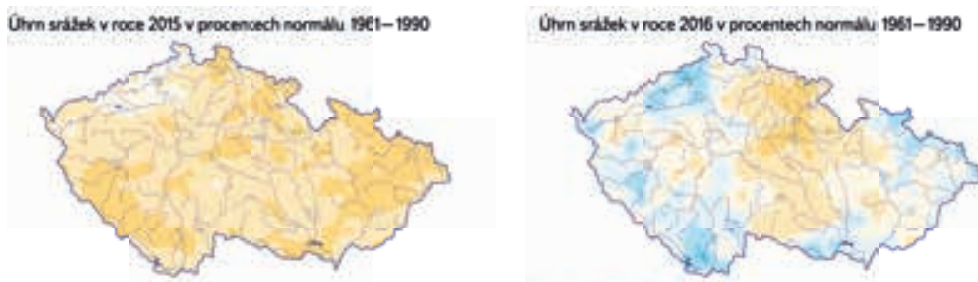

$n \rightarrow \infty=0$
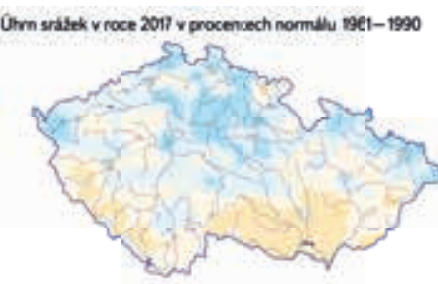

$\lim _{\infty \rightarrow \infty}$
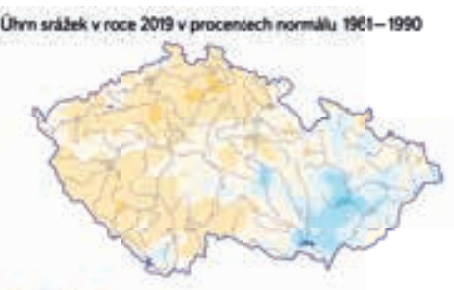

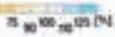

Obr. 11. Úhrny srážek v letech 2015-2019 jako procento normálu 1981-2010 (zdroj: ČHMú) Fig. 11. Amount of precipitation in 2015-2019 year period expressed as percentage normal 1981-2010 (source: ČHMÚ)

V povodí Sázavy k profilu stanice Ždár nad Sázavou byl odtok z povodí v letech 2015, 2017 a 2019 výrazně vyšší než spadlé srážky (odtokové koeficienty větší než 1) a rovněž v letech 2016 a 2018 byly podíly odtoku vưči srážkám výrazně vyšší než v ostatních zkoumaných povodích (kromě Blatného potoka). Odtoky z povodí Sázavy jsou pravděpodobně zkreslené stavebními pracemi na vodních dílech v povodí a vypouštěním Velkého Dářka při výlovu ryb na podzim. Detaily o manipulacích však autorům v době zpracování príspěvku nebyly známy. Velmi pravděpodobně dochází také k dotaci povrchového odtoku z rašeliništ v pramenné části, stejně jako u povodí Blatného rybníka.

Ve většině povodí byla maximální hodnota evapotranspirace v červnu 2019, vysoké hodnoty byly odvozeny i v roce 2017. Naopak ve velmi suchém a srážkově chudém roce 2018 vycházejí hodnoty evapotranspirace relativně nízké. V červnu 2019 byla také na všech povodích největší záporná hydrologická bilance určená podle výše uvedené rovnice (od 37 do 102 mm), což může být způsobeno již zmíněnou vysokou evapotranspirací. Nejvyšších hodnot nabývá evapotranspirace shodně $v$ měsících červnu a červenci. Lze tedy konstatovat, že z pohledu evapotranspirace byl ve zkoumané periodě 2015-2019 kritickým rok 2019.

Hydrologickou bilanci povodí významně ovlivňují manipulace na vodních dílech a malých vodních nádržích, vypouštění před výlovy rybníků, prevody vody atp. Pro správné stanovení hydrologické bilance je nezbytné mít tyto informace k dispozici a umět je při výpočtu bilance kvantifikovat. U malých vodních nádrží je z tohoto pohledu přesná kvantifikace veličin hydrologické bilance rádově obtížnější než pro velká území, jak je zpracovává ČHMú ve svých každoročních publikacích. Jako vhodné doplnění do budoucna se jeví porovnání vybraných povodí s ohledem na odvození úhrnu srážek za celé zkoumané pětiletí 2015-2019 a jeho porovnání s normálovým obdobím 1981-2010, a to $v$ širším prostorovém měřitku se zaměřením na distribuci srážek pro celé území ČR. Pro presnější zhodnocení rozdílů mezi jednotlivými povodími by bylo také vhodné rozšírit zkoumané lokality o povodí na území západních Čech a Moravy. Výsledky prezentované v tomto příspěvku jsou součástí a budou dále využity při řešení uvedeného projektu TITSMZP809.

\section{Poděkování}

Tento př́spěvek vznikl v rámci projektu Technologické agentury ČR programu BETA 2 s názvem TITSMZP809 "Vliv malých vodních nádrží na hladinu podzemních vod a celkovou hydrologickou bilanci s dưrazem na suchá období. Poděkování dále patř́ kolegům Petru Šerclovi a Kláre Sedlákové za poskytnutá rastrová data srážek a evapotranspirace.

\section{Literatura}

[1] DINGMAN S. Lawrence. Physical hydrology, third edition. University of New Hampshire, Long Grove, Illinois. 2014. ISBN 1-4786-1118-9.

[2] KEMEL, M. Klimatologie, Meteorologie, Hydrologie. Praha: ČVUT, 2000. ISBN:80-01-01456-8,

[3] LANGHAMMER, J. Hydrologie-odtokovýproces. Praha:Přírodovědecká fakulta univerzity Karlovy, 2007. Dostupné z: https://web.natur.cuni.cz/ langhamr/lectures/hydro/pdf/Hydrologie_1_Langhammer_ odtok_proces.pdf [ověřeno 26. 6.2020]

[4] Český hydrometeorologický ústav. Hydrologická bilance množství a jakosti vody České republiky 2018. Praha: Český hydrometeorologický ústav, 2019

[5] TRNKA, M. a kol. Využití predpovědi pưdni vlhkosti a intenzity sucha pro lepši rozhodování v rostlinné výrobě. Brno: Ústav výzkumu globální změny AV ČR, 2017. ISBN 978-80-87902-23-3.

[6] Česká geologická služba. Geovědní mapy 1:50 000. [on-line] 2020. Dostupné z: https://mapy. geology.cz/geocr50/ [ověřeno 26. 6. 2020]

[7] Povodí Vltavy, s. p. Plán dílčího povodí dolní Vltavy, Stav útvarů povrchových vod a program opatření v povodí horní Sázavy po soutok se Želivkou. Praha: Povodí Vltavy. 2016. Dostupné z: http:// www.pvl.cz/portal/pdp/VD/XI_Horni_Sazava/1_Text/1_Horni_Sazava_text.pdf [ověřeno 26. 6. 2020]

[8] Český hydrometeorologický ústav. Vyhodnocení sucha na území České republiky v roce 2018. Praha: Český hydrometeorologický ústav, 2019b.

\section{Autoři}

Ing. Radovan Tyl, Ph.D.'

凶radovan.tyl@chmi.cz

ORCID: 0000-0002-5270-3248

Ing. Václav David, Ph.D. ${ }^{2}$

$凶$ vaclav.david@fsv.cvut.cz

ORCID: 0000-0002-7792-9470

Ing. Adam Beran, Ph.D. ${ }^{3}$

\adam.beran@vuv.cz

ORCID: 0000-0002-8800-5599

'Český hydrometeorologický ústav

${ }^{2}$ Fakulta stavební, České vysoké učení technické v Praze

${ }^{3}$ Výzkumný ústav vodohospodářský T. G. Masaryka

Příspěvek prošel lektorským řízením.

DOI: 10.46555/VTEI.2021.03.005 
HYDROLOGICAL BALANCE IN SELECTED

WATERSHEDS OF THE CZECH REPUBLIC

WITH FOCUS ON DROUGHT PERIOD 2015-2019

\section{TYL, R. ; DAVID, V. ${ }^{2}$; BERAN, V. ${ }^{3}$}

${ }^{1}$ Czech Hydrometeorological Institute

${ }^{2}$ Czech Technical University in Prague, Faculty of Civil Engineering

${ }^{3}$ T. G. Masaryk Water Research Institute

Keywords: watershed runoff - drought -

runoff coefficient - time series - small water reservoirs

The contribution is aimed to the determination and assessment of a hydrological balance at selected watersheds in Czech Republic during the dry period 2015-2019. Hydrological balance was processed in gauging stations of watershed Blatný stream, Lomnice, Skalice, Žehrovka, Javorka, Cidlina, Botič and upper Sázava river using data from Czech hydrometeorological institute. Monthly, long-term monthly and annual values were calculated for precipitation, runoff and evapotranspiration. Results were compared across the selected watersheds and with long-term period 1981-2010. Runoffs from watersheds were compared with gauging average discharge of an entire observation period. 